\title{
DETERMINANTS OF MUSIC DEVELOPMENT AND THE INFLUENCE OF MUSIC EDUCATION ON OVERALL PERSONAL DEVELOPMENT
}

\begin{abstract}
The development of musical abilities and the space given to music education is determined by various factors. Disagreement in opinions about the role of some factors carries the danger of neglecting some activities that would contribute to the development of musical talent. In that sense, the aim of the paper is pointed at understanding the importance of hereditary and environmental factors for the development of musical abilities, with special emphasis on determining the activities of adults in the function of music education and achievement, but also overall development.

Applying the method of theoretical analysis, a comparison of different conceptual approaches was performed, as well as of the results of the conducted research and the conclusions of the authors.

After considering these issues, it is concluded that although debates about giving preference to certain factors still exist, there is no dilemma that innate and environmental factors are both important, but not in themselves without the activities of an individual. Accordingly, the role of parents, educators, and teachers in motivating and provoking children's musical development with adequate musical content, overall communication, and atmosphere was emphasized. The pedagogical implications are contained in the above recommendations for the correct approach in creating musical content and a stimulating environment.
\end{abstract}

\section{bozana.raskovic@pr.ac.rs \\ daliborka.popovic@pr.ac.rs}

Рад је примљен 9. новембра 2021, а прихваћен за објављивање на састанку Редакције 3борника одржаном 21. децембра 2021. 
Future research should be focused on examining and possibly improving the competencies of professionals-educators and teachers-to discover and support musically gifted children.

KEYWORDS: musical abilities; inheritance; environment; music education; adult support.

The influence of different factors on the development of children's musical abilities occupies the attention of a great number of researchers. Music pedagogues base their research on appraising and improving musical abilities with a view to finding the most adequate way to teach music. Music psychologists try to understand the nature and structure of musical abilities, their place in the complex organisation of all man's abilities, and their connection with personality. Both study the course of and determinants affecting musical development and search for the ways of identifying them.

Considering the determinants of musical development, Mirković Radoš (1986) outlines the discrepancies between the authors who emphasise the innateness of musical talent on the one hand (Seashore, Schoen, Révész) and the mostly behaviourism-oriented authors on the other, who claim that environmental factors are the most significant determinants in musical development (Lundin, 1953 in Matić \& Mirković Radoš, 1986, p. 35). The quoted author also points out that the majority of psychologists nowadays agrees with Farnsworth's opinion that both determinants, inheritance and environment, have importance in shaping musical abilities, the difference being merely in attributing more importance to one or the other (Farnsworth, 1958 in Matić \& Mirković Radoš, 1986, p. 35).

This paper begins with an overview of different approaches to determining musical abilities and related concepts, as well as different attitudes and research studies of nativists and empiricists on the issues of general problems and possibilities in the development of musical abilities, the questions of diagnosis and prognosis, and on the influence of music on the cognitive, social, and emotional development of children. In addition to appraising the relationship between inheritance and environment, which at the same time also determines children's participation in the development of their own musical abilities, special attention is directed towards presenting some activity recommendations for adults (parents and teachers) for the purpose of developing and supporting musical abilities and achievements. The significance of the development of musical 
abilities for the overall development of personality is also emphasised, for musical abilities encompass a wide range of man's psychophysical functions, regardless of whether they are biologically conditioned or socially encouraged.

\section{CONCEPTUAL DETERMINATION OF MUSICAL ABILITIES}

The concept of musical abilities is "one of the most controversial" in the psychology of music (Révész, 2001 in Radoš, 2010), and it is precisely the absence of any common universal approach to defining this concept that contributes to the multiplicity of related terms and presents at the same time one of the key factors in the slowness with which musical psychology as a branch has developed. When defining musical abilities, the studies that deal with children's musical development offer numerous terminological determinations: musical talent, musicality, musical ability, good ear also appears frequently, and so does musical potential.

Certain authors (Nikolić, 2016, p. 88) point out that potential and capacity can as concepts be used synonymously, and that these are determined by factors of inheritance, "aided" with informal musical experiences. When it comes to musical talent, Bogunović believes this term refers to "academic musical giftedness" and "musical performance talent" (2010, p. 62). McPherson and Williamon (2006) consider that there are several types of musical talent and they list at least eight: composing, improvising, conducting, appraising, arranging, analysing, performing, and music teaching. Musicality as a concept has not yet been determined terminologically due to its complexity. It is thought to include "the ability to understand, experience, and assess music, though not necessarily the technical aspects of the ability to produce quality performance" (Mirković Radoš, 1996, p. 36). Bogunović also determines the concept of musicality as "the ability to react to music, sensitivity to the aesthetic and affective value of music, as well as the ability to understand, experience, and assess music" (2010, p. 74). A good ear is most commonly defined as the most basic criterion for involvement with music, and it entails the ability to intone the required pitch, whereas musicality is reflected in the aesthetically expressed moment of interpretation (Vasiljević, 1978, p. 67). "Musical abilities, in their broadest meaning, are the primary factor in musical success and 
the prerequisite for speaking about learning music and acquiring vocal and instrumental performing competencies" (Bogunović, 2010a, p. 73). Mirković Radoš (1998) believes that the fundamental musical abilities needed for musical success include, above all, the ability to differentiate the pitch, rhythm, dynamics, duration and timbre, as well as melodic and rhythmic memory.

Accordingly, it can be concluded that musical abilities entail a system of psychological characteristics necessary for performing different kinds of musical activities: perceiving, reproducing, and creating music. They appear as elementary, basic musical phenomena (the perception of pitch, dynamics, rhythm, duration), which are relatively resistant to environmental influences in the form of complex abilities of aesthetic appraisal and experience of listening to and reproducing music (Nikolić, 2016), which in turn implies a large number of factors in the complex long-term process of developing musical abilities.

\section{THE IMPORTANCE OF INHERITANCE IN THE DEVELOPMENT OF MUSICAL ABILITIES}

Each person is born with certain innate characteristics, which are shared by or the same in all people, as well as with certain specific inherited characteristics typical of each individual. The former originated in the process of man's evolution as a species, while the latter are inherited from one's ancestors. These form the inheritance foundation of man's psychophysical life and behaviour. The inherited is not manifested immediately and automatically in the form of readily-available unchangeable abilities and characteristics, but only as certain dispositions. Each genotype contains an unlimited number of development possibilities, so these dispositions can develop in different ways, and the limits of their development are hard to determine, so they can also dwindle or disappear unless there are adequate conditions, education, and activities of trainees themselves (Trnavac \& Đorđević, 2005). A great number of researchers has made efforts to answer the question of whether there are any behavioural signals that might indicate later development of specific abilities. They have usually used age-standardised tests of musical abilities to assess musical abilities. These tests have included Seashore's Measurement of Musical Salent (Seashore et al., 1960 in Rojko, 1981, p. 29) and Gordon's Primary Measures of Music 
Audiation (Gordon, 1979 in Mirković Radoš, 1996, p. 65). Their aim is to test perception, not performance, so they do not rely on either performance or conceptual training. These tests consist of listening to two short music excerpts, with the respondent assessing whether they are the same or different. Considering the fact that perceptual competence appears in one's development before performing competence, children can be expected to show abilities in such perceptual tests even before they demonstrate performing skills (Leman et al., 2012, p. 52).

A great number of studies (O'Neill, 1997 in Leman et al., 2012) do not establish any clear relationship between test results at an early age and later musical performance, which is why many pedagogues are reserved when it comes to making any final decisions on music education after giftedness test results. The reason for caution in attributing any importance to test results is grounded in the fact that these results are largely influenced by motivational and emotional factors, which often have little to do with the realistic level of abilities (Leman et al., 2021). Namely, many differences among people are genetically conditioned, but in psychology it is extremely difficult to determine genetic contribution to behavioural differences as many of them can also be a product of society and environment, not merely genetics.

Based on Seashore's view, supported by experiments, it has been determined that elements of musical talent such as identifying the pitch, rhythm, dynamics, and colour of tone are innate and at work since early childhood. Gestalt-oriented researcher Révész (Révész, 1925; 1954 in Mirković Radoš, 1996) also considers that musicality is innate. The most disputed part of Révész's critical thought is his emphasis on innate musicality being distributed among the population on the "all or nothing" principle.

Ksenija Mirković Radoš (1996) sums up a great number of studies on the inheritable components of musical abilities, from Seashore's (1919) to Bentley's (1966), in the following way:

a) Research into family trees (genealogical research) of famous musicians points out that a considerably greater number of talented offspring came from families with gifted ancestors;

b) Measurement tests have proved that increase in the degree of kinship correlates positively with the increase in matching musical abilities;

c) It is assumed that brain physiology conditions the presence of certain forms of musical abilities (Mirković Radoš, 1996, p. 44). 
Seashore and his followers' conception of the hereditary factor of musicality has in the last decades been many times disputed and abandoned as unacceptable. Some more recent research has, however, yielded interesting results which support Seashore's view. Some such results come from a Swedish research study into the influence of musical practice on the development of musical abilities. The research included an assessment of melodic and rhythmical abilities as well as auditory discrimination of the pitch using the sample of 10,500 twins. The results showed that there was no difference in musical abilities between those twin couples who invested a different amount of time in practice. This finding suggests that musical practice does not have any causal effect on musical abilities the genetic factor instead does (Mosing et al., 2014). Galton (in Grujić, 2017, p. 85) studied the genealogy of 120 prominent musicians, among whom the most famous were Johann Sebastian Bach's family members, and he reached the conclusion that genius is inherited. The arguments used to dispute his claims focused on the fact that talented virtuosi were raised in similar musically stimulated family environments. As an argument in favour of inheritance, Galton pointed out great individual differences among family members as children do not psychologically experience the same environment in the same way.

A number of researchers identifies the term musical abilities with potential, and a number of them in turn considers that musical potential is inherited. Haroutounian $(2008$, p. 3 ) emphasises that musical potential offers the possibility to detect musical talent before music education begins. McPherson and Williamon (2006, p. 240) understand potential as "natural abilities that have a genetic origin and that appear and develop more-or-less spontaneously in every individual." According to the quoted authors, genetic base can explain the differences in the results of those individuals who are affected by approximately the same environmental conditions. While Haroutounian observes capacity and potential as synonymous, Mirković Radoš considers that capacity implies innate musical abilities, which makes it an essential factor in musical achievement, and that musical potential refers to a combination of genetic factors and early informal experience (Mirković Radoš, 1996).

In his book This Is Your Brain on Music, author Daniel J. Levitin (2006), a musician and neuroscientist, stresses the importance of the early recognition of talent, which requires that children's skill 
development be studied. The reason why some children acquire skills faster than others probably lies in genetic factors, but it is difficult to single out possible additional factors, which probably include the influence of environment (motivation, personality, and family dynamics). Similar factors can have impact, as the author emphasises, and thus mask the contribution of genetics to musical abilities.

Brain research has not so far been of much use in solving these perplexities because separating cause from consequence is not easy. The mentioned author presents a series of studies that all try to discover the origin of talent. Having gathered brain recordings of people with absolute pitch, Gottfried Schlaug (2001) from Harvard proved that the auditory cortex region (planum temporale) is larger in the brain of absolute listeners in comparison to other people. This indicates which part of the brain is in charge of absolute pitch, but it does not explain whether this part is larger from the beginning for those that obtain absolute pitch, or if the acquisition of absolute pitch enlarges the planum. Additionally, the research of violinists conducted by Thomas Elbert (1995) showed that the cerebral region responsible for moving the left arm becomes larger due to practice. The firmest evidence of talent is that some people can simply acquire skills faster than others (Schlaug, 2001; Elbert, 1995 in Levitin, 2006).

Gembris and Davidson (2002) point out that the overall development of people is under the influence of genetic factors: maturation, physical capacity, and mental capacity. According to these authors, the hereditary component is a significant determinant which also affects musical development. More recent genetic research has deepened our understanding of the hereditary component of musicality. In research in which absolute-listener respondents took part, a certain number of the human genome areas was detected, which confirmed the relationship with absolute pitch (Theusch et al., 2009 in Nikolić, 2015, p. 74). Research results showed that people who inherit adequate physiological structure and organisation of the brain choose to become involved with music. In addition, biological evidence also points out that practice in music causes changes in cerebral structure and function (Schlaug \& Gaser, 2003). To this effect, the referenced findings lead towards the conclusion that any genetic inheritance can be improved by the musically stimulating environment (Hallam, 2006). 


\section{THE IMPORTANCE OF ENVIRONMENT IN THE DEVELOPMENT OF MUSICAL ABILITIES}

The previously presented interpretation of the development of musical abilities belongs to the nativism-oriented researchers and theoreticians, who overestimate the role of inheritance, whereas empiricism-oriented authors on the other hand overestimate the role of environment. The essence of their critical thought is that environment does not only influence the development of hereditary dispositions, but learning also creates new dispositions. Social environment, especially the relationship between parents or other important persons and children, determines development degree of children's abilities. From that point of view, the development of an individual is achieved by the effect of environment on what the individual brought into this world as inheritance, as well as on what has already been developed under environmental influence. In this process, an individual is not passive but more or less active. In accordance with their hereditary and acquired dispositions, individuals also influence their environment (Nešić \& Radomirović, 2000). Lehman's detailed analysis (1996) of famous pianist "child prodigies" from the $17^{\text {th }}$ to the $20^{\text {th }}$ century, which did not discover any single case of a child not being provided with exceptionally enriched educational conditions since the earliest age (Lehman, 1996 in Leman et al., 2012), also speaks pronouncedly in favour of social environment. The Bach, Couperin, or Mozart family are also exemplary as regards the considerable influence of musically-motivating family environment. Mirković Radoš (1996) stresses that some critics of the hereditary standpoint insist that a great number of gifted offspring in families with musically gifted ancestors can be accounted for by the musically-motivating environment. To this effect, the quoted author sums up the studies in favour of environmental factors, pointing out that:

a) there is a positive influence of musically-stimulating family environment on the development degree of musical abilities,

b) certain musical characteristics can be improved by practice in music, which confirms that a child can improve specific musical attributes (Mirković Radoš, 1996, p. 44).

What also speaks in favour of arguing that environment is significant for the development of musical abilities is the appearance of experimental methods for testing the knowledge of babies, which is 
revolutionary in the study of musical development. Based on measuring subtle changes in body movements (turning their heads or eyes, or the speed of suckling) or internal processes (the pulse), researchers have established some data on the baby's consciousness of environmental change (Leman et al., 2012). Innovative techniques have revealed that sensitivity to music exists even before birth, which some authors (Leman et al., 2012) support with the results of numerous studies. For instance, new-borns pay more attention to the music their mothers played to them before they were born than to new melodies (Harper, 1991); perceiving and memorising specific information about music is possible because hearing develops prenatally as early as by the end of the fourth month (Lacanuet, 1996). Further, Trainor and Trehub's research (1993) discovered that five-month-old babies are more sensitive to a melodic pattern or motive than to the pitch. In this respect, babies show the same musical intelligence as older children or adults. In their experiment, the same authors trained nine-month-old babies to react to changes in dynamics when the same melodic excerpt was repeated to them. Whenever the dynamics was changed, the babies received a prize if they turned their heads at least 40 degrees to the left. The prize was activating a certain mechanical toy (Harper, 1991; Lacanuet, 1996; Trainor \& Trehub, 1993 in Leman et al., 2012, p. 41). Therefore, long before they learn to produce recognisable words or chants, babies indicate with their voice that they have musical abilities. The cited experiments were conducted in the context of interaction between the infants and their carers (most often mothers). Infants imitate the pitch and melodic patterns they hear in adult speech (Kessen et al., 1979 in Leman et al., 2012, p. 42). The highlighted results have proved that musical ability is a universal and inherent human ability (all described achievements refer to average babies). The authors have also emphasised that literature on the abilities of infants lacks any studies to confirm the presence of great individual differences among babies as regards musical abilities.

THE ROLE OF PARENTS, INDIVIDUALS' ACTIVITIES AND TEACHER SUPPORT IN MUSICAL DEVELOPMENT

There is general agreement among researchers that parents play the most important role in discovering children's musicality and 
their creative abilities, developing their sensibility and inciting interest in and love of music. Research studies dealing with the effect of parents' support on the musical achievements of children have reached the conclusion that musically successful students were given parents' support and encouragement in the early stages of their musical development (Sloboda \& Howe, 1991 in McPherson \& Williamon, 2006, p. 247). Davidson (1996) concludes that parents' early engagement and stimulation as regards music correlates strongly with children's later musical achievements (Davidson et al., 1996 in Leman et al., 2012, p. 57).

If daily lives provide children with enough opportunity to participate in musical activities, they will in all likelihood develop these skills faster than those children who only listen to music passively. As the first and most prominent aspect of everyday life, family home and the extent of musical activities at home will most likely have significant influence on musical development, and an important role as regards the values that a child adopts in respect of forming musical abilities is also played by peer groups. Groups of musically active peers can have influence on the development of musical interest. The described claims are also contained in behavioural theories, which support the thesis that "surrounded by its environment, an organism emits different responses, of which only those that are sustained will be kept in the behaviour repertoire" (Nešić, 2003). Musical achievements are far more widespread in some non-western cultures. Studying the Anang Ibibo of Nigeria, Messenger (1958) notices some amazing abilities that these people, especially children, possess. The children of this tribe can sing hundreds of songs before the age of six, both solo and chorally, and they are able to play several percussion instruments and can perform a great number of dance moves. The concept of being "unmusical" or "untalented" does not exist in this tribe (Messenger, 1958 in Davidson et al., 2009). Musical songs and dances initiated by parents are largely jeopardised in the media-dominated cultures, so additional efforts are often required for explaining to parents what they should do.

Contact with musical instruments in the family environment allows children to listen to, try, and select the most suitable instrument (Rašković, 2019). Michel's research study (1973) established that a child's musical development can be encouraged if a family member plays an instrument. 
Literature stresses that in addition to inheritance and environment, what also matters is a relatively independent factor in development-activity (Nešić \& Radomirović, 2000, p. 86). Few people make great achievements in music. Variations in the extent of achievement correspond to the changes in individuals' music education, their resulting identity and professional role in society (Leman et al., 2012, p. 28). In the literature on development, some authors (Leman et al., 2012) point out that children mostly lack the ability to focus systematically on learning specific techniques of a certain instrument until the age of four. However, musical games based on singing, dancing, and movement can be successfully introduced as soon as the child shows the first signs of being capable of focused and controlled reaction. What should be pointed out is that teaching at an early age demands a large amount of adept adult support, interaction, and motivation.

Suzuki claims that "[a]ll children skilfully reared reach a high educational level but such rearing must start from the day of birth" (Suzuki, 1983, p. 4), with the correct orientation and methodological approach; he also stresses the important role of parents in early music education. Parents are expected to be present at the classes that the child attends and thus expand their own knowledge about music as well as supervise and assist the child's practice. Some parents are themselves musically trained simultaneously with their children so as to better understand what is expected from children and help them to achieve it. Apart from individual teaching, Suzuki's method also insists on group classes because children enjoy them more while also learning a lot when they play with older students. Institutions, starting with the family as well as preschool and school, exercise their influence on child's musical development through the general atmosphere and activities that are performed in them, communication and relationship with children, and the communication they create among peers. To this effect, in addition to their influence on creating good mood, they also develop children's wish to participate in musical activities, whereby they contribute to musical experience, creativity, and the holistic development of personality (Nešić, 2003).

Jeremić and Milenović (2017, p. 154) also discuss the role of teachers in discovering and supporting musically gifted children, pointing out that teachers' role focuses on their competence and skill to instruct children in mastering cognitive, emotional, and psychomotor processes of knowledge acquisition with a view to 
developing their giftedness. These complex processes are carried out and provided for each child by the teachers, with the aim of identifying certain abilities that are above average-giftedness (Popović et al., 2016). This is why their goals are complex and set high since early and unskilful assessment of the children who exhibit an ability above average can stifle the ability instead of advancing it.

Especially suitable for working with gifted children is tutorial teaching, which includes "encouragement and support until the potential of the gifted students is fully developed" (Jovanović \& Minić, 2018).

The connection between musically encouraging environment and the achieved level of musical abilities is among the most researched problems in the psychology of music. Summing up a large number of verified findings, Mirković Radoš concludes that researchers agree that "the fulfilment of musical potential and maximum level of performance are achieved by early identification of giftedness, family orientation towards consistent and continuous encouragement of the child within the appropriate cultural, pedagogical, and musical level, as well as by competent music education" (Mirković Radoš, 1996, p. 269).

\section{THE INFLUENCE OF MUSIC AND MUSIC EDUCATION ON CHILD'S OVERALL DEVELOPMENT}

It is important to emphasise that "through education, a child adopts certain values, ideas, beliefs, customs, as well as behaviour patterns which are required by cultural environment" (Nikolić \& Antonijević, 2020, p. 486). Therefore, the development of musical abilities needs to be observed within the framework of adequate music education, and the effect of music and music education on the development of cognitive, social, and emotional abilities needs to be analysed.

The connectedness between music and cognition can be viewed from two independent research areas. The first one studies short-term effects of listening to music, while the second deals with the effect of music education on the improvement of non-musical areas of knowledge. The first published results (Rauscher et al., 1995) of research on the "Mozart effect" established a link between listening to music and cognitive abilities. This research also 
encouraged numerous other studies and debates about music education and its effect on child development. Rauscher's first experiment (1993) proved that students who had been listening to a Mozart sonata for ten minutes showed considerably better results in the subsequent spatial reasoning test than two other groups of students who had during that same period been either listening to a different kind of music or spending their time quietly before the test. The attempts to replicate the "Mozart effect" proved that neither Mozart's music nor music in general causes better results in the tests of spatial-temporal, creative, and other cognitive abilities. The cause of success in the test is the optimal emotional state that can be stimulated by listening to one's favourite music, singing one's favourite song, or else by other non-musical influences (Jackson \& Tlauka, 2004; Schellenberg \& Hallam, 2005; Schellenberg \& Weiss, 2013). The conclusion was that this kind of effect creates short-term cognitive advantages.

In the research (Rauscher et al., 1995; Chan et al., 1998; Rauscher \&Zupan, 2000; Vaughan, 2000; Hetland, 2000; Schellenberg, 2004; Fauvel et al., 2006) that deals with the connection between music education and cognitive development, the respondents who had certain education in music showed more successful results in different tests. These tests measured mathematical, verbal, and non-verbal abilities. The cited research studies have concluded that more successful results of musically educated respondents derive from the overall intelligence, which is a shared component that can be significantly influenced by an external factor.

The research dealing with preschool and early school children has proved that active involvement with music has effect on the development of creativity (Kalmar, 1982; Wolff, 1979 in Hallam, 2010b), which has also been confirmed by the research that included high school and college students of music (Hallam, 2010b). Those studies that deal with the connection between music education and academic success contain observations that training in music contributes by stimulating learning and encouraging children to actively participate in personal learning, which is the key factor that leads towards academic success (Blasi \& Foley, 2006). Schellenberg (2004) considers that attending school increases intelligence, just as music education has positive effect on the increase of intelligence. He presumes that the link between music education and intellectual skills is one of cause and effect. Schellenberg and Weiss (2013) have derived the conclusion that the connectedness between 
music education and intelligence is positive when musical activity is additional to regular education.

The research that has focused on social and emotional development of children contains significant implications which indicate the importance of music education in child development. The research dealing with preschool and school children who had attended a programme in music education showed that these children were more willing to cooperate and help one another in solving problems (Kirchner \& Tomasello, 2010). Children who had attended a programme in music education also showed better results in empathy tests (Rabinowitch et al., 2013). Music teachers have pointed out the positive effect of music education on the development of love of and enjoyment in music, but also on the development of social skills such as team work, the feelings of achievement, self-confidence, and perseverance (Hallam \& Prince, 2000). Participation in group musical activities directs children's attention to one another, transferring it from an individual onto group level. Group musical activities contribute to the sense of belonging, performance experience, discipline, and bigger self-respect (Brown, 1980). Some studies have shown that interaction in a musical group influences the development of empathy and respect (Hallam, 2010a), while also raising the amount of self-esteem (Rickard et al., 2013).

Particularly important social-emotional skills that have influence on the future academic success include the group of skills known as self-regulation. By means of these skills, children can control impulsiveness, become more careful and goal-oriented as well as able to organise and plan their activities. Other research results (Scott, 1992; Kochanska et al., 1996; Kochanska et al., 2000) proved that participation in music programmes has significant contribution to the development of self-regulation in preschool children. The effects of musical achievements depend on a large number of factors, and among those already mentioned, an important place is occupied by fine coordination between adult (parents' and teachers') attitudes and demands.

CONCLUSION The influence of music and an individual's musicality cannot be viewed outside social context. The feelings aroused in one by listening to music are not affected by the form or quality of the music that is being performed or listened to, but rather by what music means to one as a member of a certain society or social group. Fun- 
damental education is based on understanding social relations and social skills, and it can be obtained through the contents of different subjects at preschool and early school level. As Jeremić and Milenović have pointed out (2020, p. 445), it is through educational contents that "the function of music teaching can be a determining factor which either advances or undermines the choice of cultural concepts and adoption of social contents."

Although the debate on the primacy of inheritance or environment remains ongoing, there are actually no dilemmas. No research has so far negated the importance of inheritance to musical development. Those musical dispositions that are inherited from ancestors are considered basic, but they cannot be separated from additional factors that influence them. The overview of the determinants of musical development has presented differing attitudes between the authors who stress the innateness of musical talent on the one hand, and on the other those of mostly behavioural orientation, who emphasise environmental factors as crucial determinants of musical development. Still, the majority of researchers agrees with the thesis that neither factor, that is, neither inheritance nor environment, can create a musician by itself, and that correlation between the two is important, as well as an individual's activity. Diagnosing musical talent is merely the foundation for the future musical development, and everyday factors such as adult (above all, parental) support and continuous practice make inseparable part of stimulating musical development.

The influence of music and music education on child development is extremely big, as showed by research results of numerous scientists who have dealt with this issue. Many researchers attribute considerable importance to early musical stimulation and its significance for activating a child's personality and enabling a healthy approach to a child's psychophysical characteristics.

According to the findings of a great number of empirical research studies and psychological theories, the psychophysical and musical development of an individual is throughout their life influenced by three significant factors: inheritance, environment, and activity. Preschool and early school children will develop great differences as regards what they can do in terms of music. How these differences in abilities are formed, and what kind of consequences they leave on education and training, are questions that musicians, pedagogues, and children's families all wish to understand. Having considered the influence of inheritance and environ- 
ment on musical and psychophysical development, we agree with those researchers who believe that fulfilling musical potential and reaching maximum performance level is achieved by early identification of giftedness, musically stimulated family environment, and competent music education.

Future research should be directed towards the role of teachers and their skills and competencies in discovering and providing support for the musically gifted children.

REFERENCES Blasi, M. J. \& Foley, M. B.(2006). The music, movement, and learning connection. Childhood education, 82(3), 175-176.

Bogunović, B. (2010). Muzički talenat i uspešnost. Beograd: Fakultet muzičke umetnosti / Institut za pedagoška istraživanja.

Bogunović, B. (2010a). Muzički talenat i uspešnost. Beograd: Fakultet muzičke umetnosti i Institut za pedagoška istraživanja.

Brown, J. D. (1980). Identifying problems facing the school band movement, Elkhart: Gemeinhardt Co. Ltd.

Chan, A.S., Ho, Y-C. \& Cheung, M.C. (1998). Music training improves verbal memory. Nature, 396, 128. doi:10.1038/24075.

Davidson, J., Faulkner, R. \& McPherson, G. (2009). Motivating musical learning: how to create the right conditions to take our natural interest in music to the next level.The psychologist, The British Psycological Society, 22 (12), 1026-1029.

Fauvel, J., Flood, R. \& Wilson, R. J. (2006). Music and mathematics: From Pythagoras to fractals.Oxford: Oxford University Press.

Gembris, H. \& Davidson, J. W. (2002). Environmental influences. In: R. Parncutt, \& G.E. McPherson (Eds.), The science and psychology of music performance: Creative strategies for teaching and learning (17-30). Oxford, New York: Oxford University Press.

Grujić Garić, G.(2017.). Uticaj faktora nasleđa, sredine, uzrasta i pola na razvoj muzičkih sposobnosti dece predškolskog uzrasta. Inovacije u nastavi, (30) 4, 84-98, DOI: 10.5937/inovacije1704084G.

Hallam, S. \& Prince, V. (2000). Research into instrumental music services. London: DfEE.

Hallam, S. (2006). Music psychology in education. London: Institute of education, University of London.

Hallam, S. (2010a). 21st century conceptions of musical ability. Psychology of music, 38, 308-330.

Hallam, S. (2010b). The power of music: its impact on the intellectual, personal and social development of children and young people. In: S. Hallam \& 
A. Creech (Eds.), Music education in the 21st century in the United Kingdom (2-17). London: Institute of education, University of London.

Haroutounian, J. (2008). Kindling the spark: Recognizing and developing musical talent. $10^{\text {th }}$ Asia-Pacifik Conference on Giftedness, Singapore, http://hkage.org.hk .

Hetland, L. (2000). Learning to make music enhances spatial reasoning. Journal of aesthetic education, 34(3/4), 179-238.

Jackson. C. S. \& Tlauka, M. (2004). Route-learning and the Mozart effect.Psychology of music, 32(2), 213-220.

Jeremić, B. i Milenović, Ž. (2017). Uloga vaspitača i učitelja u prepoznavanju i pedagoškoj podršci darovitoj deci. U: M. Šćepanović, (ur.). Tematski zbornik radova međunarodnog značaja Darovitost, s međunarodnog naučnog skupa održanog u Novom Sadu, 29. 9. - 1. 10. 2017. godine (146-157). Novi Sad: Udruženje građana Mensa Srbije.

Jeremić, B. i Milenović, Ž. (2020). Društveni kontekst nastave muzičke kulture $\mathrm{u}$ funkciji negovanja tradicionalnog narodnog stvaralaštva Srba. Baština, 31(52), 441-460.

Jovanović, M. i Minić, V. (2018). Vrste nastavnog rada sa darovitim učenicima u redovnoj nastavi. Baština, 26(46), 125-141.

Kalmar, M. (1982). The effects of music education based on Kodaly's directives in nursery school children.Psychology of music, Special Issue, 63-68.

Kirschner, S. \& Tomasello, M. (2010). Joint music-making promotes prosocial behavior in 4-year-old children.Evolution and human behavior, 31, 354-364.

Kochanska, G., Murray, K. \& Harlan,E. T.(2000). Effortful control in early childhood: Continuity and change, antecedents and implications for social development.Developmental psychology, 36, 220-232.

Kochanska, G., Murray, K., Jacques, T. Y., Koenig A. L. \& Vandegeest, A. V. (1996). Inhibitory control in young children and its role in emerging internalization.Child development, 67, 490- 507.

Leman, A., Sloboda, Dž. i Vudi, R. (2012). Psihologija za muzičare: razumevanje $i$ sticanje veština. Novi Sad: Psihopolis institut.

Levitin, D.J. (2006). This is your brain on music: The science of a human obsession. New York: Dutton.

Matić, E. i Mirković, K. (1986). Muzika i predškolsko dete. Beograd: Zavod za udžbenike i nastavna sredstva.

McPherson, G. \& Williamon, A. (2006). Giftedness and talent. In: G. McPherson (Ed). The child as musician: A handbook of musical development(239-256). Oxford: Oxford University Press.

Michel, P. (1973). Optimum development of musical abilities in the first years of life. The psychology of music, 1, 14-20. 
Mirković Radoš, K. (1996). Psihologija muzike. Beograd: Zavod za udžbenike i nastavna sredstva.

Mirković Radoš, K. (2010). Psihologija muzike. Beograd: Zavod za udžbenike i nastavna sredstva.

Mosing, M., Madison, G., Pedersen, N. L., Kuja-Halkola, R. \& Ullén, F. (2014). Practice does not make perfect.Psychological science, 25 (9),1795-1803.

Nešić, B. i Radomirović, V. (2000). Osnove razvojne psihologije. Jagodina: Učiteljski fakultet.

Nešić, V. (2003).Muzika, čovek $i$ društvo: Socijalno-psihološki pristup. Niš: Filozofski fakultet u Nišu, DIGP „PROSVETA”-NIŠ

Nikolić, I. (2016). Procena muzičkih sposobnosti u procesu identifikacije muzički talentovanih učenika mlađeg školskog uzrasta (unpublished doctoral dissertation). Vranje: Učiteljski fakultet.

Nikolić, L. (2015) Faktori sticanja i razvoja muzičkih kompetencija kod studenata učiteljskih fakulteta (unpublished doctoral dissertation). Beograd: Fakultet muzičke umetnosti.

Nikolić, N. i Antonijević, R. (2020). Obrazovanje kao faktor kulturne reprodukcije i kulturne produkcije. Baština, 33 (51), 483-496.

Popović, D., Lazović, M., \&Milosavljević, Ž. (2016). Podrška razvijanju darovitosti u školskoj praksi. Inovacije u nastavi, (29) 3, 73-83

Rabinowitch, T. C. Cross, I. \& Burnard, P. (2013). Long-term musical group interaction has a positive influence on empathy in children.Psychology of music, 41, 484-498.

Radoš, K. (2010). Psihologija muzike (drugo dopunjeno izdanje). Zavod za udžbenike, Beograd.

Rašković, B. (2019). Činioci muzičkih sposobnosti dece Raškog okruga u predškolskom uzrastu (unpublished doctoral dissertation). Bijeljina: Akademija umjetnosti.

Rauscher, F. H. \& Zupan,M. A. (2000). Classroom keyboard instruction improves kindergarten children's spatial-temporal performance: A field experiment.Early childhood research quarterly, 15, 215-228.

Rauscher, F. H., Shaw, G. L. \& Ky, K. N. (1995). Listening to Mozart enhances spatial-temporal reasoning: Towards a neurophysical basis. Neuroscience letters, 185, 44-47.

Rickard, N. S., Appelman, P., James, R., Murphy, F., Gill, A. \& Bambrick, C. (2013). Orchestrating life skills: The effect of increased school-based music classes on children's social competence and self-esteem. International journal of music education, 31, 292-309.

Rojko, P. (1981). Testiranje u muzici. Zagreb, Muzikološki zavod Muzičke akademije u Zagrebu. 
Schellenberg, G. E. \& Hallam, S. (2005). Music listening and cognitive abilities in 10 and 11 year olds: The Blur effect.Annals of the New York Academy of Sciences, 1060, 202-209.

Schellenberg, G. E. \& Weiss, M. W. (2013). Music and cognitive abilities. In: D. Deutsch (Ed.), The psychology of music (499-550). Amsterdam: Elsevier.

Schellenberg, G. E. (2004). Music lessons enhance IQ.Psychological science, 15, 511-514.

Schlaug, G. \& Gaser, C. (2003). Brain structure differ between musicians and nonmusicians.Neuroscience, 9240-9245.

Scott, L. (1992). Attention and preseverance behaviours of preschool children enrolled in Suzuki violin lessons and other acitivities. Journal of research in music education, 40 (3), 225-235.

Suzuki, S. (1983). Nurtured by love: The classic approach to talent education. Princeton: Summy-Birchard.

Trnavac, N.i Đorđević, J. (2005). Pedagogija: Udžbenik za nastavnike. Beograd, Naučna knjiga komerc.

Vasiljević, Z. (1978). Metodika nastave solfeđa. Beograd: Univerzitet umetnosti.

Vaughn, K.(2000). Music and mathematics: Modest support for the oft-claimed relationship. Journal of aesthetic education, 34(3-4), 149-166.

БОЖАНА М. РАШКОВИЋ

ДАЛИБОРКА Р. ПОПОВИЋ

УНИВЕРЗИТЕТ У ПРИШТИНИ СА ПРИВРЕМЕНИМ СЕДИШТЕМ

У КОСОВСКОЈ МИТРОВИЦИ, УЧИТЕЉСКИ ФАКУЛТЕТ

ОДСЕК ЗА ПЕДАГОГИЈУ

КАТЕДРА ЗА МЕТОДИКУ НАСТАВЕ

РЕЗИМЕ

ДЕТЕРМИНАНТЕ МУЗИЧКОГ РАЗВОЈА И УТИЦАЈ МУЗИЧКОГ ОБРАЗОВАҢА НА УКУПАН РАЗВОЈ ЛИЧНОСТИ

Развој музичких способности и простор који се даје музичком образовању детерминисан је различитим чиниоцима. Неусаглашеност у мишљењима о улози неких фактора носи опасност од занемаривања неких активности које би ишле у сусрет развијању музичке даровитости. У том смислу, циљ рада је усмерен на сагледавање значаја наследних и срединских фактора за развој музичких способности, са посебним освртом на утврђивање активности одраслих у функцији музичког образовања и постигнућа, али и укупног развоја. 
Примењујући методу теоријске анализе, извршено је упоређивање различитих концептуалних приступа и резултата спроведених истраживања и закључака аутора.

Након разматрања наведених питања, закључује се да, иако дебате око давања предности одређеним факторима и даље постоје, дилеме нема, значајни су и урођени и средински фактори, али не сами по себи без активности појединца. Оне музичке диспозиције које се од предака наслеђују сматрају се базичним, али их не можемо издвојити од додатних фактора који на њих утичу. Утицај музике и музичког образовања на развој детета је изузетно велики, што наводе резултати истраживања великог броја научника који су се овом темом ठавили. Многи истраживачи придају велики значај раној музичкој стимулацији и њеном значају за активирање дечје личности и омогућавању здравог приступа његовим психофизичким карактеристикама. Дијагностиковање музичког талента само је темељ на коме почиње будући музички развој, а свакодневни чиниоци, као што су подршка одраслих, пре свега, родитеља и континуирано вежठање, неизоставни су у стимулацији музичког развоја. Сходно томе, истакнута је улога родитеља, васпитача и учитеља у мотивацији и провокацији дечјег музичког развоја адекватним музичким садржајима, свеукупном комуникацијом и атмосфером. Педагошке импликације су садржане управо у наведеним препорукама за правилан приступ у креирању музичких садржаја и подстицајне средине.

Будућа истраживања потребно је усмерити на испитивање и могућности унапређивања компетенција професионалаца-васпитача и учитеља за откривање и подршку музички даровите деце.

КљУчНЕ РЕчи: музичке способности; наслеђе; средина; музичко образовање; подршка одраслих.

Овај чланак је објављен и дистрибуира се под лиценцом Creative Commons Ауторство-Некомерцијално Међународна 4.0 (СС BY-NC 4.0 |

https://creativecommons.org/licenses/by-nc/4.0/).

This paper is published and distributed under the terms and conditions of the Creative Commons Attribution-NonCommercial International 4.0 licence (CC BY-NC 4.0 | https://creativecommons.org/licenses/by-nc/4.0/). 